\title{
RELEVANSI FINALITAS KRISTUS \\ DI TENGAH-TENGAH ARUS PLURALISME DAN PLURALITAS MASYARAKAT INDONESIA
}

\author{
Aya Susanti \\ Sekolah Tinggi Theologia Jaffray Jakarta \\ Jl. Jatinegara Timur II / 35 Jakarta Timur 13350 \\ Email: ayasusanti70@gmail.com
}

\begin{abstract}
Aya Susanti, Relevance finality of Christ in the Middle Flow Plurality And Pluralism Indonesia Society. From age to age the human perspective of the person and role of Jesus Christ is changing. The shift from an absolute way of thinking about Christianity also occur in the Western world and even in Indonesia. Contemporary skepticism about the possibility of knowing the truth is growing. In response to the phenomenon of multiple perspectives and beliefs and teachings that exist in Indonesian society locus of the finality of Jesus Christ it is necessary to present a written explanation for the answer. By studying several aspects of relevance, both with regard to timing issues, teaching the meaning and context it is expected that there are embodiments value finality fitting that in a pluralistic society in Indonesia.
\end{abstract}

Keyword: Finality of Christ, Supremacy, Biblical Theology, Pluralism, Indonesia Society.

ABSTRAK: Aya Susanti, Relevansi Finalitas Kristus Di Tengah-Tengah Arus Pluralisme Dan Pluralitas Masyarakat Indonesia. Dari zaman ke zaman perspektif manusia terhadap pribadi dan peran Yesus Kristus berubah-ubah. Pergeseran dari cara pemikiran yang absolut tentang kekristenan juga terjadi di dunia Barat dan bahkan di Indonesia. Masa kini skeptisme mengenai kemungkinan untuk mengetahui kebenaran semakin berkembang. Menyikapi berbagai perspektif dan fenomena keyakinan serta ajaran yang ada di lokus masyarakat Indonesia mengenai finalitas Yesus Kristus ini maka dipandang perlu untuk menghadirkan sebuah pemaparan tertulis untuk menjawabnya. Dengan mempelajari beberapa aspek relevansi, baik berkaitan dengan masalah waktu, makna pengajaran dan konteks maka diharapkan ada pengejawantahan nilai finalitas yang pas yang di dalam masyarakat pluralis Indonesia.

Kata Kunci: Finalitas Kristus, Supremasi, Teologi Alkitabiah, Pluralisme, Masyarakat Indonesia.

\section{PENDAHULUAN}

Finalitas Kristus merupakan azas primer di dalam kekristenan. Apabila Kristologi telah berubah esensi menjadi sekunder dan menjadi tidak mutlak, maka kekristenan telah kehilangan esensi pokoknya. Adanya berbagai isu yang mengemukakan mengenai berbagai pandangan yang langsung maupun tidak langsung berdampak pada tergerusnya core atau inti pengajaran tentang finalitas Yesus. Fenomena ini penulis deteksi dalam praktik kehidupan sehari-hari maupun dalam diskusi ilmiah mendorong penulis untuk membahas isu ini. Isu ini menjadi semakin menarik untuk dibahas karena berkaitan dengan arus pluralisme dan pluralitas masyarakat Indonesia. Indonesia sebagai negara yang beragam budaya, su$\mathrm{ku}$, dan agama sangat lekat dengan pluralitas masya- rakatnya serta masyarakat Indonesia adalah masyarakat yang hidup bersama dengan rukun dan damai di tengah-tengah keragaman budaya dan agama. Dengan fakta yang ada di lapangan, di era modern, postmodern $^{1}$ sampai era digital, kemajemukan selalu menjadi ciri khas bangsa Indonesia. Sementara itu Enggar Objantoro dalam jurnalnya mengatakan pluralisme merupakan isu yang sangat menonjol pada

\footnotetext{
${ }^{1}$ Postmodern merupakan era setelah era modern dan dimengerti sebagai upaya mengungkapkan segala konsekuensi dari berakhirnya modernisme. Ciri dari postmodern adalah relativisme dan kebenaran dipandang sebagai sesuat yang relatif. I Putu Ayub Darmawan, "Pendidikan Kristen Di Era Postmodern", Jurnal Simpson: Jurnal Teologi dan Pendidikan Agama Kristen, Volume 1, Nomor 1, Juli 2014: 38-39. http://journal. sttsimpson.ac.id/index.php/Js/article/view/3/2
} 
masa kini dan dalam konteks Indonesia, kesadaran dan pemahaman yang benar tentang pluralisme agama-agama masih perlu untuk dikembangkan. ${ }^{2}$

Berkaitan dengan hal tersebut di atas maka pertanyaan penting yang perlu dikemukakan berkaitan dengan hal ini adalah bagaimana relevansi finalitas Kristus di tengah-tengah arus pluralisme dan pluralitas masyarakat Indonesia? Untuk menjawab pertanyaan tersebut maka melalui artikel ini penulis menjawab pertanyaan tersebut dengan menguraikan relevansi finalitas Kristus bagi teologi Alkitabiah dan relevansi finalitas Kristus bagi kehidupan orang Kristen di tengah-tengah arus pluralisme dan pluralitas masyarakat Indonesia.

Pembahasan dalam artikel ini dibagi menjadi dua bagian, yaitu relevansi finalitas Kristus bagi teologi Alkitabiah dan relevansi finalitas Kristus bagi kehidupan orang Kristen di tengah-tengah pluralisme dan pluralitas masyarakat Indonesia.

\section{METODE}

Untuk membahas topik ini, penulis melakukan sebuah kajian dari beberapa sumber pustaka. Kajian ini merupakan penelitian kualitatif yang mengkaji sumber-sumber pustaka sebagai sumber data yang kemudian diuraikan dalam sebuah uraian sistematis sesuai dengan kerangka berpikir yang penulis kemukakan. Penulis memilih beberapa sumber pustaka yang berkaitan dengan topik bahasan dan disertai beberapa pendapat teolog yang mengajar pada beberapa Perguruan Tinggi Teologi di Indonesia untuk mendukung pembahasan topik. Sumber utama dalam penelitian ini adalah (1) Yesus Bagi Orang Non Religius karya John Shelby Spong terbitan Gramedia, 2008; (2) Kristus yang Tiada Tara karya John Stott yang diterbitkan oleh Momentum, 2007; (3) Supremasi Kristus karya Ajith Fernando yang

${ }^{2}$ Enggar Objantoro, "Pluralisme Agama-Agama: Tantangan Bagi Teologi Kristen”, Jurnal Simpson: Jurnal Teologi dan Pendidikan Agama Kristen, Volume 1, Nomor 1, Juli 2014: 61. http://journal.sttsimpson.ac.id/ index.php/Js/article/view/3/2. diterbitkan oleh Momentum, 2006; (4) Kristus Sang Kontro Versialis yang ditulis oleh John Stott dan diterbitkan dalam bahasa Indonesia oleh Literatur Perkantas Jawa Timur. Untuk mendukung uraian dalam karya tulis ini, penulis meminta pendapat beberapa teolog di Indonesia seperti (1) Pinehas Djenjengi, Dosen Sekolah Tinggi Theologia Jakarta; (2) Andreas Himawan, Ketua Sekolah Tinggi Teologi (STT) Amanat Agung; (3) Stevri Lumintang, Penulis buku Teologi Abu-Abu; (4) Martin Sinaga, Dosen STT Jakarta; (5) Timothy Joshua, Dosen STT Iman. Data-data yang diperoleh dari sumber-sumber tersebut kemudian disajikan dalam uraian sesuai dengan kerangka berpikir penulis.

\section{TINJAUAN UMUM RELEVANSI FINALITAS KRISTUS BAGI TEOLOGI ALKITABIAH}

\section{Pengertian Relevansi}

Secara umum, arti dari relevansi adalah kecocokan. Relevan adalah bersangkut paut, berguna secara langsung. Relevansi berarti kaitan, hubungan. Menurut Green (1995:16), relevansi ialah sesuatu sifat yang terdapat pada dokumen yang dapat membantu pengarang dalam memecahkan kebutuhan akan informasi. Dokumen dinilai relevan bila dokumen tersebut mempunyai topik yang sama, atau berhubungan dengan subjek yang diteliti (topical relevance). Pada berbagai tulisan mengenai relevance, topicality (topik) merupakan faktor utama dalam penilaian kesesuaian dokumen. Froelich dalam Green (1995:16) menyebutkan bahwa inti dari relevance adalah topicality. Joan M. Reitz (2004:606) mengemukakan bahwa "relevance the extent to which information retrieved in a search of a library collection or other resource, such as an online catalog or bibliographic database, is judged by to user to be applicable to (about) the subject of the query. Pendapat ini menyatakan bahwa relevansi merupakan sejumlah informasi terpanggil dalam sebuah pencarian pada koleksi perpustakaan atau sumber lainnya, seperti catalog online atau basis data bibliografi, 
yaitu informasi yang diberikan sesuai dengan subjek pada query dan relevan dengan kebutuhan pengguna. $^{3}$

\section{Pengertian Relevansi Finalitas Kristus bagi Teologi Alkitabiah}

Dalam kaitannya dengan finalitas Kristus bagi teologi alkitabiah, penulis membahasnya dengan relevansi waktu, pengajaran, sejarah dan kehidupan praktis orang percaya. Makna relevansinya dengan waktu, itu berarti bahwa finalitas Kristus berlaku untuk jangka waktu yang tidak terbatas. Tidak pernah kadaluarsa atau expired bagi para penggunanya atau bagi para pemercaya. Sedangkan dari sisi pengajaran, itu berarti pengajaran yang solid, yang primer, yang absolut, tidak dapat direduksi. Karena dengan mengizinkan kompromi, kondisi ini akan menggerus langsung ke intinya, apabila ajaran ini kehilangan intinya finalitas Kristus ini akan kehilangan makna aslinya dari Alkitab.

Dari sisi sejarah, relevansi ini bersifat membuktikan. Telah terbukti sejak kehadiran Yesus Kristus di dalam dunia ini sampai pada kenaikanNya ke surga, bahkan sampai kedatangan-Nya kembali, ajaran ini akan terus berlangsung bahkan bersifat progresif karena dengan diri-Nya sendiri, Dia yang akan mengajar umat-Nya. Semuanya ini akan mendatangkan manfaat yang besar apabila para pemercaya mengaplikasikannya ke dalam kehidupan praktisnya sehari-hari.

\section{RELEVANSI BAGI TEOLOGI ALKITABIAH}

\section{Relevan Sepanjang Masa}

Menelusuri relevansi finalitas Kristus, dari abad pertama hingga abad kedua puluh satu kekristenan adalah hal yang tidak mudah. Hal ini menjadi sulit dikarenakan perubahan paradigma pemikir dan pemercaya yang terus berkembang. Mengamati fe-

\footnotetext{
${ }^{3}$ N.n. Universitas Sumatera Utara, 1.
}

nomena tersebut, Fernando menuliskan hal ini dengan jelas sekali:

Supremasi Kristus: judul ini saja sudah terlihat berada di luar cara berpikir orang-orang masa kini. Apakah orang-orang yang cerdas masih berpegang pada perilaku yang dianggap sudah kuno ini sehingga mereka masih bisa berbicara tentang supremasi Kristus? Banyak orang yang berpikir bahwa semakin cepat sisa-sisa mentalitas penjajahan ini dienyahkan dari gereja, semakin cepat pula keadaan akan membaik. Ini menunjukkan bahwa setiap masa dalam sejarah membawa tantangan baru bagi apologetika dan formulasi theologis dalam gereja. Pada masa kini, pluralisme telah menjadi filsafat yang dominan, agama-agama Timur telah mengadopsi sikap misioner yang kuat, pemikiran Zaman Baru sedang berusaha menerobos masuk ke dalam berbagai bidang kehidupan masyarakat Barat, sedangkan evangelikalisme, terutama di Barat, kelihatannya telah kehilangan komitmennya kepada kebenaran Injil yang radikal. ${ }^{4}$

\section{Finalitas Kristus Dalam Alkitab}

Walaupun serangan terhadap pribadi Yesus dilancarkan dari abad ke abad, namun ada satu fakta yang tidak dapat disangkal oleh semua orang di dalam sejarah kehidupan manusia di planet bumi, itu adalah mengenai Yesus sebagai pusat sejarah. Tentang hal ini, Stott menulis:

Yesus adalah pusat dari sejarah. Sedikitnya satu porsi besar umat manusia terus membagi sejarah menjadi Sebelum Masehi dan Sesudah Masehi dengan merujuk kepada kelahiran-Nya. Pada tahun 2000, populasi dunia mencapai 6.000 juta jiwa, sedangkan jumlah orang Kristen diperkirakan sebesar 1.700 juta jiwa, atau sekitar 28 persen. Maka hampir sepertiga umat manusia mengaku mengikut Dia. ${ }^{5}$

Kristus Sebagai Pusat Pemberitaan Perjanjian Lama Hasel di dalam bukunya mengulas gagasan von Rad yang menyatakan bahwa Perjanjian Lama

${ }^{4}$ Ajith Fernando, Supremasi Kristus (Surabaya: Momentum, 2006), xiii.

${ }^{5}$ John Stott, Kristus yang Tiada Tara (Surabaya: Momentum, 2007), 1. 
adalah sebuah kitab sejarah. Kitab ini mengisahkan sejarah Allah dengan Israel, dengan bangsa-bangsa, dan dengan dunia, sejak penciptaan sampai kepada hal-hal yang terakhir, maksudnya, sampai kepada saat penguasaan dunia diserahkan kepada Anak Manusia (Dan. 7:13). Beberapa pengakuan iman yang mula-mula sekali (Ul. 26) ditetapkan secara historis, maksudnya, "pengakuan iman itu mengaitkan nama Allah ini dengan sebuah pernyataan tentang tindakan tertentu di dalam sejarah. ${ }^{6}$ Von Rad menerangkan, "Sejarah ini dapat disebut sebagai sejarah penyelamatan [Heilsgeschichte] karena, sebagaimana yang disajikan, penciptaan itu sendiri dipahami sebagai tindakan penyelamatan dari Allah dan karena menurut apa yang dinubuatkan oleh para nabi, kehendak Allah untuk menyelamatkan adalah untuk mencapai sasaran itu, sekalipun ada banyak tindakan penghakiman. Jadi, telah jelas bahwa von Rad memakai pemahamannya tentang sejarah Perjanjian Lama sebagai suatu skema hermeneutis untuk menafsirkan Perjanjian Lama.

Teolog-teolog seperti Bengel, Beck dan von Hofmann menerangkan hubungan antara kedua Perjanjian dalam arti rencana keselamatan Allah yang lengkap dan berkesinambungan. Sedangkan teologi Alkitab modern, pada segi lain, menekankan ketidaksinambungan, baik dalam Perjanjian Lama sendiri maupun di antara Perjanjian Lama dan Perjanjian Baru. Von Rad menolak pandangan ekstrem tentang kesinambungan dan ketidaksinambungan yang demikian dan mengusulkan adanya kesatuan antara kedua Perjanjian dengan pengertian bahwa "tujuan sebenarnya hubungan Allah dengan Israel adalah kedatangan Yesus Kristus". Ia berpendapat bahwa ada suatu "analogi struktural" antara peristiwa-peristiwa penyelamatan dalam Perjanjian Lama dan Perjanjian Baru. Peristiwa-peristiwa Perjanjian Lama dimengerti dalam konteks karya Allah dalam sejarah, yang digenapi dalam Yesus Kristus. Sesungguhnya

${ }^{6}$ Gerhard F. Hasel, Teologi Perjanjian Lama (Malang: Gandum Mas, 1992), 129. hanya dalam peristiwa Kristus, analogi dan penyesuaian dengan peristiwa-peristiwa sebelumnya menjadi sungguh-sungguh berarti:

Kedatangan Yesus Kristus secara nyata dalam sejarah tidak memberi pilihan bagi penafsir; penafsir harus menafsirkan Perjanjian Lama sebagai kitab yang menunjuk pada Kristus, sehingga Kristus harus dipahami dalam cahaya Perjanjian Lama. Kristus perlu sekali untuk memahami Perjanjian Lama dan Perjanjian Lama perlu sekali untuk memahami Kristus. Tanpa peristiwa penyelamatan Perjanjian Baru, Perjanjian Lama hanya akan dimengerti secara tidak sempurna; dan tanpa Perjanjian Lama, kesaksian Perjanjian Baru terhadap Kristus terpaksa ditafsirkan ulang secara radikal. ${ }^{7}$

Penggenapan Perjanjian Lama oleh Yesus membawa dua akibat. Pertama, Yesus Kristus menunjukkan makna sebenarnya perjanjian yang lama bagi penyataan. Kedua, peristiwa-peristiwa perjanjian yang lama membeberkan secara jelas aspek-aspek tertentu peristiwa penggenapan itu, yakni penyataan Allah dalam Kristus. Dengan demikian Perjanjian Lama berfungsi sebagai saksi tentang karya penyelamatan Allah dalam sejarah. Dari pembahasan di atas dapat disimpulkan bahwa yang menjadi pusat Teologi Perjanjian Lama adalah karya penyelamatan Allah yang akan digenapi di dalam pribadi Mesias, Sang Juruselamat dunia yakni Yesus Kristus. Jadi, di dalam Perjanjian Lama, supremasi Kristus telah diproklamasikan jauh sebelum kehadiran-Nya secara fisik di dalam sejarah kehidupan manusia.

\section{Kristus Sebagai Pusat Pemberitaan Perjanjian Baru}

Tujuan utama Perjanjian Baru ialah bersaksi tentang suatu peristiwa sejarah, yakni kelahiran, pelayanan, kematian dan kebangkitan Yesus Kristus. Peristiwa ini unik, sebab di dalamnya Allah sendiri telah campur tangan di dunia untuk menyelamatkan manusia; tetapi peristiwa ini tidak terisolasi, sebab merupakan titik tengah suatu sejarah yang berlanjut dari penciptaan dunia hingga akhir zaman. Pada segi

${ }^{7}$ David L. Baker, Satu Alkitab Dua Perjanjian (Jakarta: Gunung Mulia, 2006), 163-163. 
lain, Perjanjian Baru menghubungkan Yesus dengan sejarah masa lalu, menunjukkan Dia sebagai puncak karya Allah dalam penciptaan dan dalam sejarah Israel.

Perjanjian Baru menegaskan bahwa akhir zaman sudah mulai dalam Yesus Kristus, yang menunjukkan makna peristiwa-peristiwa Perjanjian Lama sepenuhnya dengan memberi konteksnya yang lengkap. Jadi penafsiran Perjanjian Lama secara Kristen adalah akibat langsung dari iman kepada Yesus Kristus. Di dalam Kristus setiap peristiwa Perjanjian Lama mendapat konteks eskatologis sehingga arti sepenuhnya menjadi terang, dan sekaligus peristiwa itu menerangi peristiwa pokok sejarah keselamatan (kedatangan Kristus). Dalam peristiwa kedatangan Kristus, Allah telah menggenapi janjijanji dan memenuhi tuntutan-tuntutan Perjanjian Lama. Oleh karena itu, inti hubungan antara kedua Perjanjian menyangkut sejarah, bukan ajaran; suatu hubungan antara dua rangkaian peristiwa dalam rencana sejarah keselamatan yang saling melengkapi, bukan antara dua kumpulan kebenaran yang kekal. ${ }^{8}$

Perjanjian Baru mengangkat konsep sejarah keselamatan dari Perjanjian Lama sebagai mata rantai peristiwa yang dihubungkan oleh janji dan penggenapan, sambil menambahkan suatu unsur baru pada konsep penggenapan. Unsur baru itu ialah Yesus Kristus, yang tidak sekadar memperpanjang perjanjian yang lama melainkan menggantikannya dengan yang lain, yaitu dengan kerajaan Allah yang eskatologis. Penggenapan yang sepenuhnya ini tidaklah asing bagi Perjanjian Lama; sebaliknya, di dalam penghubungan peristiwa-peristiwa secara profetik oleh janji dan penggenapan menemukan tujuannya. Lagi pula, penafsiran Kristen akan Perjanjian Lama harus didasarkan pada pemahaman tentang penggenapan ini, sebab hanya dengan demikianlah penafsiran itu sesuai dengan penafsiran profetik akan sejarah. $^{9}$

\footnotetext{
${ }^{8}$ Ibid, 182.
}

${ }^{9}$ Ibid, 182.
Finalitas Kristus Dalam Sejarah Gereja

Kristologi menunjukkan kepada manusia bagaimana Allah datang pada manusia untuk menyingkirkan penghalang antara Allah dan manusia, dengan cara memenuhi syarat-syarat hukum dalam Kristus, dan memperbarui manusia agar dapat memasuki kembali persekutuan dengan Tuhan dalam keadaan penuh berkat. Antropologi berorientasi kepada perhatian Allah yang penuh kasih dalam persahabatan dengan manusia, yang menunjang kehidupan persekutuan yang penuh berkat Allah; akan tetapi janji seperti itu hanyalah berlaku di dalam dan melalui Kristus. Dengan demikian, doktrin Kristus sebagai Pengantara perjanjian itu juga harus demikian. Kristus, yang telah dijadikan tipe dan dinubuatkan dalam Perjanjian Lama sebagai Penebus manusia, datang dalam waktu yang telah ditetapkan, menjadi manusia di antara manusia dan menyebabkan manusia memperoleh perdamaian kekal.

\section{Masa Konsili Kalsedon}

Dalam literatur Kristen abad mula-mula, Kristus disebutkan sebagai Allah dan manusia, Anak Manusia, juga Anak Allah. Keberadaan-Nya yang tanpa dosa terus dipegang teguh, dan Ia adalah tujuan penyembahan yang paling benar. Memang masalah yang timbul tentang Kristus, yang pada saat yang sama adalah Allah dan juga manusia, dan kesulitan-kesulitan yang tercakup dalam konsep ini, belum sepenuhnya dirasakan oleh orang Kristen abad mula-mula tersebut. Mereka hanya melihatnya sebagai suatu kontroversi. Pada zaman gereja mula-mula, ada lagi kelompok lain yang memiliki doktrin Kristologi yang disusun atas dasar yang mirip dengan itu. Mereka juga menganggap bahwa Yesus hanyalah manusia biasa, walaupun secara ajaib dilahirkan oleh seorang perawan dan mereka mengajarkan bahwa Kristus turun ke atas Yesus pada saat baptisan, menyebabkan Dia memiliki kekuatan supranatural. Umumnya pendapat ini sama dengan pendapat Monarkhi Dinamis. Paulus dari Samosata adalah tokoh utama ajaran yang membedakan antara Yesus 
dan Logos. Paulus dari Samosata menganggap Yesus adalah manusia, sama seperti manusia lain, dilahirkan oleh Maria; sedangkan Logos dianggap sebagai pemikiran Ilahi yang tidak berpribadi, yang kemudian tinggal dalam Kristus dalam pengertian praeminen, sejak waktu baptisan-Nya, dan dengan demikian memberikan kualitas bagi tugas-tugas-Nya yang besar. Dari sudut pandang penyangkalan ini, maka tugas para tokoh apologetika abad mula-mula adalah mempertahankan doktrin keilahian Kristus.

Pada saat doktrin keilahian Allah Putra ditetapkan secara resmi, muncul pertanyaan mengenai hubungan keterkaitan kedua natur Kristus. Jalan keluar dari persoalan ini ditawarkan oleh Apollinaris dengan cara menerima pandangan Yunani tentang konsep trikotomi dalam diri manusia yaitu tubuh, jiwa dan roh. Ia berpendapat bahwa Logos mengambil posisi roh (pneuma) dalam diri manusia, yang ia anggap sebagai posisi dosa. Ia terutama tertarik pada usaha menekankan kesatuan pribadi Kristus. Akan tetapi ia melakukan hal ini dengan mengorbankan kemanusiaan yang lengkap dan pribadi Kristus, tanpa mengorbankan keilahian-Nya yang sesungguhnya; dan juga untuk tetap mempertahankan ketidakberdosaan-Nya. Ia melakukan hal ini dengan mengorbankan kemanusiaan Juruselamat dan tentu saja pendapatnya ditolak oleh Konsili Konstantinopel tahun 381. Apollinaris hanya memenuhi satu hal saja, yaitu kesatuan pribadi Kristus. Bahaya ini menjadi nyata di dalam pandangan aliran Antiokhia, yang membesar-besarkan perbedaan antara kedua natur Kristus.

Theodore dari Mopsuestia dan Nestorius menekankan kemanusiaan Kristus yang utuh, dan mengatakan bahwa Logos yang tinggal di dalam diri-Nya hanya sekedar moral yang tinggal pada-Nya, sebagaimana juga dinikmati oleh orang-orang percaya, walaupun tidak pada derajat yang sama. Mereka melihat bahwa di dalam diri Kristus ada manusia yang berdampingan dengan Allah, bersekutu dengan Allah, memiliki tujuan yang sama dengan Allah, tetapi tidak menyatu dengan Dia di dalam kesatuan hi- dup pribadi yang tunggal, seorang Pengantara yang terdiri dari dua pribadi. Bertentangan dengan pendapat mereka, Cyril dari Alexandria sangat menekankan kesatuan pribadi Kristus. Lawan-lawannya menganggap ia menyangkal kedua natur Kristus. Kendati pun mereka itu dalam segala kemungkinan salah paham terhadapnya, Eutychus dan para pengikutnya jelas menyetujuinya ketika mereka menerima pendapat bahwa natur manusia dalam diri Kristus diambil oleh natur Ilahi, atau bahwa kedua natur itu bercampur menjadi satu natur tunggal. Ini merupakan pendapat yang termasuk dalam penyangkalan atas dua natur Kristus. Konsili Kalsedon tahun 451 menetapkan kesatuan dalam pribadi Kristus dan dua natur yang ada dalam diri-Nya. Pinehas Djenjengi merumuskan hasil Konsili Kalsedon sebagai berikut:

Di kalangan Gereja Katolik selama abad XVIXVIII, Kristologi tidak mengalami perubahan atau pembaharuan yang berarti. Kristologi yang dikembangkan hanya menjelaskan lebih jauh rumusan iman konsili Chalcedon-Konstantinopel dan menjabarkannya menjadi lebih terperinci. Kristologi tetap sebagai "kristologi dari atas". 10

\section{Setelah Konsili Kalsedon}

Kekeliruan Eutychus untuk sementara waktu, tetap diteruskan oleh kaum Monofisit dan Monotelit, tetapi kemudian gereja berhasil memperbaikinya. Bahaya selanjutnya adalah bahwa natur manusia Kristus dapat dianggap sepenuhnya impersonal, ditentang oleh Leontius dari Byzantium, ketika ia menunjukkan bahwa natur manusiawi Kristus itu bukanlah impersonal tetapi inpersonal, dalam pribadi, yang memiliki subsistensi pribadi dalam pribadi Anak Allah.

Abad Pertengahan hanya memberikan sedikit sumbangsih kepada doktrin pribadi Kristus. Dengan adanya berbagai pengaruh seperti tekanan terhadap imitasi Kristus, teori tentang penebusan dan perkembangan doktrin tentang misa, gereja tetap memegang teguh kepenuhan kemanusiaan Kristus.

\footnotetext{
${ }^{10}$ Pinehas Djenjengi, Wawancara oleh penulis,
} Oktober 2014. 
Dalam pandangan Kristologinya, sebagian kaum Skolastik menyajikan pandangan doketis tentang Kristus. Peter the Lombard tidak ragu-ragu mengatakan bahwa dipandang dari sudut kemanusiaan-Nya, Kristus sebenarnya bukan apa-apa. Akan tetapi pendapat nihilisme seperti ini amat dikutuk gereja. Beberapa pokok baru dinyatakan oleh Thomas Aquinas. Aquinas mengemukakan konsep seminar ferby tentang Sang Logos yang menebarkan benih di berbagai tempat seperti yang Andreas Himawan kemukakan sebagai berikut:

Thomas Aquinas menghidupkan, memunculkan konsep-konsep tentang seluruh kebenaran adalah kebenaran Allah dan itu diajarkan oleh Yesus Kristus. Konsep tentang seminar ferby yaitu firman itu menaburkan benihnya di berbagai tempat dan tentu bisa ditemukan oleh manusia dan memang konsep tentang kesingularitas Yesus dan supremasi Kristus. Melalui kemampuan akal manusia bisa memahami Allah, bisa mengerti Allah. Mereka punya konsep mengenai grace, perfecting, natur, natur itu sudah sangat luar biasa namun belum lengkap makanya perlu grace yaitu anugerah Allah melalui Yesus untuk melengkapinya. Tetapi karena penekanan naturnya itu begitu kuat sehingga pelan-pelan bisa seperti kesingularitas Yesus itu agak tergerus dan terlihat sekali di dalam theology liberal. ${ }^{11}$

Menurut Aquinas, pribadi Logos menjadi komposit dalam inkarnasi, dan kesatuan-Nya dengan kemanusiaan "menghalangi" kemanusiaan itu untuk sampai pada keadaan kepribadian yang tidak terikat. Natur manusiawi Kristus menerima dua macam anugerah berkenaan dengan persatuan-Nya dengan Logos, yaitu a) Gratia unionis, yang memberikan kepadaNya suatu kebangkitan istimewa, sehingga dapat menjadi tujuan penyembahan, dan b) Gratia Habitualis yang menunjang hubungan-Nya dengan Allah. Pengetahuan manusiawi Kristus ada dua yaitu pengetahuan yang ditanamkan dan pengetahuan yang diperoleh. Ada dua kehendak dalam diri Kristus, akan tetapi sebab yang utama adalah kehendak Ilahi, di mana kehendak manusiawi selalu terletak di bawah kehendak Ilahi.

\section{Menjelang Abad Sembilan Belas}

Reformasi tidak membuat perubahan besar dalam doktrin pribadi Kristus, baik gereja Roma dan gereja-gereja Reformasi menerima doktrin Kristus sebagaimana dikemukakan dalam konsili Kalsedon. Perbedaan-perbedaan antara kedua gereja ini terletak pada masalah lain. Ada satu ciri utama Kristologi dari gereja Lutheran yang harus dikemukakan. Doktrin Luther akan kehadiran fisik Kristus dalam perjamuan kudus membawa pada pandangan Lutheran yang khas yaitu communicatio idiomatum, yang menyatakan bahwa "setiap natur Kristus mengalirkan natur yang lain 'perichoresis', dan bahwa kemanusiaan-Nya mengambil bagian dalam atribut-atribut Ilahi-Nya." Mereka berpegang bahwa sifat manusia Kristus pada saat inkarnasi. Segera timbul pertanyaan, bagaimana mungkin pendapat seperti ini dapat diselaraskan dengan apa yang diketahui tentang Kristus selama hidup di bumi. Pertanyaan ini mengakibatkan pendapat-pendapat yang berbeda di antara teolog Lutheran. Sebagian berpendapat bahwa Kristus menyingkirkan sifat-sifat Ilahi yang Ia terima pada saat inkarnasi atau hanya memakai sifa-sifat itu pada waktu tertentu, sedang yang lain berpendapat bahwa Ia tetap memiliki sifat-sifat itu sepanjang masa kehidupan-Nya di dunia, akan tetapi hanya memakainya secara diam-diam. Sebagian teolog Lutheran tampaknya cenderung untuk menyingkirkan doktrin ini. Teolog Reformed melihat adanya pendapat Eutychianisme atau campuran kedua natur Kristus dalam doktrin Lutheran. Teologi Reformed juga mengajarkan adanya komunikasi antara atributatribut Ilahi, tetapi memandangnya dengan cara yang berbeda. Teologi Reformed percaya bahwa setelah inkarnasi, segala sifat dan karakteristik dari kedua natur dapat ditujukan pada satu pribadi Kristus. September 2014. 


\section{Sampai Abad Sembilan Belas}

Pada abad 19 suatu perubahan besar terjadi dalam bidang studi tentang pribadi Kristus. Sampai masa itu titik awal setiap studi Kristologi adalah teologis, dan Kristologi yang dihasilkannya bersifat teosentris; akan tetapi selama masa akhir abad 18 ada suatu pendapat yang terus berkembang bahwa hasil yang lebih baik dapat dicapai dengan cara memulainya lebih dekat dengan manusia, yaitu dengan cara mempelajari Yesus yang historis. Dengan demikian dimulailah masa yang disebut sebagai "masa Kristologis kedua". Sudut pandang yang baru ini bersifat antropologis dan sifatnya jelas antroposentris. Pendapat ini mengakibatkan hancurnya iman gereja. Perbedaan yang sangat jauh dan menyolok telah dibuat antara Yesus yang historis, yang digambarkan oleh para penulis Injil, dan Kristus yang teologis, yang merupakan buah dari imajinasi subur dari para pemikir teologis dan yang imajinasinya tercermin da lam pengakuan iman gereja. Kristus yang supranatural memberi jalan bagi manusia Yesus; dan doktrin tentang dua natur memberi jalan bagi doktrin suatu manusia Ilahi.

Seluruh pengajaran modern tentang Kristus didasarkan pada doktrin kontinuitas Allah dan manusia. Dan mereka yang tidak setuju doktrin ini segera mengumandangkan suaranya, seperti Barth dan mereka yang sepikiran dengannya. Ada beberapa golongan yang memberikan indikasi kembali kepada doktrin dua natur Kristus. ${ }^{12}$

Supremasi Kristus dalam Natur Kemanusiaan-Nya dan Supremasi Manusia Kristus dalam Sejarah Manusia. Kedua tema ini dipilih karena mempertimbangkan bahwa walaupun kaum pluralis berusaha menyangkal Supremasi Kristus dalam perspektif eksklusivisme doktrin keselamatan, yang tentu saja wacananya lebih banyak menekankan mengenai sisi keilahian-Nya namun dari sisi kemanusiaan-Nya, Yesus tetap memiliki supremasi yang tidak terban-

${ }^{12}$ Louis Berkhof, Teologi Sistematika (Jakarta: Lembaga Reformed Injili Indonesia, 1996), 20. tahkan dan tidak dimiliki oleh pendiri dan pengikut agama-agama di dunia.

\section{Supremasi Kristus dalam Natur Kemanusiaan}

Spong, dalam bukunya yang ditujukan kepada orang-orang non-religius menulis tentang gambaran asli Yesus. Setelah mengupas fakta insani Yesus bebas dari mitos, Spong melihat Yesus dipahami sebagai Paskah Baru, Yesus dipahami di bawah simbol Yom Kippur, Yesus sebagai Anak Manusia, Yesus sebagai Sang Hamba, Sang Raja Gembala, Yesus: Seorang Manusia untuk Semua Musim Yahudi. ${ }^{13}$

\section{Yesus Dipahami Sebagai Paskah Baru}

Bukti alkitabiah sendiri membuat jelas bahwa makna penyaliban merupakan hal terpenting dalam kisah Yesus dan bahwa kematian-Nya ditafsirkan sejak awal sekali berdasar latar belakang Paskah Yahudi. Namun, hubungan dengan Paskah Yahudi ini tidaklah harus berarti hubungan sejarah; dengan demikian, penyelidikan harus dimulai dengan menantang gagasan yang dipahami harafiah bahwa Yesus disalib pada waktu Paskah. Markus, Matius, dan Lukas menempatkan kematian Yesus pada waktu Paskah dengan menyamakan Perjamuan Terakhir dengan perjamuan Paskah Yahudi. Injil keempat, Injil Yohanes, juga membuat hubungan ini, tetapi ini dilakukan dengan menyatakan bahwa hari penyaliban adalah hari penyembelihan domba Paskah; ini berarti bahwa bagi Yohanes Perjamuan Terakhir bukan perjamuan Paskah, tetapi suatu perjamuan persiapan memasuki Paskah. Paskah telah menarik Yesus dan murid-murid-Nya ke Yerusalem. Seluruh kisah penyaliban diberitakan sebagai suatu bagian dari perayaan Paskah. Yesus dan romobongan murid-Nya sebetulnya masuk ke kota suci itu, menurut Injil-Injil, seminggu sebelumnya. Masuknya Yesus ke Yerusalem sekarang masih dirayakan sebagai hari

\footnotetext{
${ }^{13}$ John Shelby Spong, Yesus Bagi Orang Non Religius (Jakarta: Gramedia, 2008), 189.
} 
pertama dari apa yang orang Kristen sebut Minggu Suci. Namun jika kita teliti kisah-kisah ini dengan cermat, ditemukan bingkai-bingkai waktu berbeda bagi penyaliban dan juga simbol-simbol yang tampaknya diangkat sangat harfiah dari suatu perayaan Yahudi lainnya yang terpisah jauh dari Paskah dalam kalender Yahudi. Injil ditulis untuk mengundang manusia masuk ke dalam pengalaman akan Yesus, pengalaman akan suatu kehidupan baru, kehidupan yang tidak dibatasi oleh kematian; dan masuk ke dalam suatu kemanusiaan baru, kemanusiaan yang mencapai keadikodratian. Jika melihat penyaliban Yesus ditarik ke dalam orbit Paskah dan menerima fakta bahwa Yesus telah dipahami menurut analogi domba Paskah, manusia melangkah masuk ke dalam keseluruhan dimensi baru makna Yesus dan keseluruhan dimensi baru apa artinya menjadi manusia. Ini juga membuka pintu masuk ke dalam suatu kekristenan baru. $^{14}$

\section{Yesus Dipahami di Bawah Simbol Yom Kippur}

Sebelum Injil ditulis, ingatan akan Yesus telah dengan luar biasa dibentuk oleh satu hari khusus dalam kalender liturgi Yahudi, yang dikenal sebagai Yom Kippur, atau Hari Pendamaian. Begitu Yesus dikaitkan dengan anak domba kurban Paskah Yahudi, mungkin nyaris tidak terelakkan ia segera dikaitkan dengan seekor anak domba kurban lainnya yang digunakan pada suatu hari suci Yahudi lainnya. Yom Kippur menawarkan kemungkinan itu. Kaitan-kaitan ini taat asas dan jelas. Anak domba Paskah dan anak domba Yom Kippur keduanya dibunuh. Keduanya dipandang menawarkan suatu bentuk keselamatan melalui penumpahan darah. Darah anak domba Paskah tertuju pada ketakutan manusia akan kematian. Darah anak domba kurban Yom Kippur tertuju pada kerinduan yang dianggap ada pada manusia untuk bersatu dengan Allah dan pada kesadaran bahwa kesatuan ini telah dihancurkan oleh keterasingan, kesalahan, dan dosa. Kedua kegiatan liturgis ini

\footnotetext{
${ }^{14}$ Ibid, 187.
}

menjadi sarana orang Yahudi melihat dalam suatu kematian hewan liturgis sebuah pintu masuk yang mereka lewati secara liturgis dalam perjalanan kehidupan mereka untuk tiba pada suatu pengertian baru mengenai apa artinya hidup utuh dan menyeluruh.

\section{Yesus Sebagai Anak Manusia}

"Anak manusia" mungkin sekali adalah gelar tertua dan paling populer bagi seseorang yang memenuhi pengharapan mesianik orang Yahudi. Ini adalah sebuah ungkapan yang dimulai dengan cukup bersahaja, tetapi terus berkembang sampai mencakup klaim-klaim tentang kekuasaan adikodrati dan dipenuhi dengan konotasi keilahian dan keajaiban. Pada dirinya sendiri, gelar ini adalah satu pintu lagi yang melaluinya manusia dapat berjalan lebih jauh ke dalam penelitian untuk memahami dimensi-dimensi pengalaman Yesus yang orisinil. Ungkapan "Anak Manusia" memasuki tradisi orang Yahudi terutama melalui tradisi tulisan nabi Yehezkiel di abad keenam S.M.; ia seorang nabi besar pada zaman pembuangan. Yehezkiel memakai frasa "Anak Manusia" lebih dari sembilan puluh kali, tetapi selalu hanya sebagai gelar yang dipakai Allah untuk memanggilnya, sebagai contoh, "Hai anak manusia, bangunlah dan berdiri, karena Aku hendak berbicara dengan engkau" (Yeh. 2:1). Kata-kata "Anak Manusia", ben Adam dalam bahasa Ibraninya, tampaklah berarti sedikit lebih dari "manusia". Ben adalah kata kedua Ibrani untuk "anak (laki-laki)" dan adam adalah sebuah kata Ibrani untuk "umat manusia". Aslinya, gelar ini sedikit lebih dari sebuah penunjukan status Yehezkiel sebagai seorang anak Adam dan dengan demikian seorang manusia.

Matius memperluas pengidentifikasian Yesus dengan gambar Daniel mengenai "Anak Manusia" dengan memakai frasa ini sebanyak dua puluh tujuh kali. Yang lainnya jelas dipenuhi jauh lebih banyak makna yang dipakai Daniel. Dalam Injil Matius, Yesus dikatakan mengutus dua belas murid-Nya untuk suatu misi dengan pengajaran ini: "Sesungguhnya sebelum kamu selesai mengunjungi kota-kota 
Israel, Anak Manusia sudah datang” (Mat. 10:23). Ketika Matius membuat Yesus menyatakan bahwa nasib "Anak manusia" telah ditetapkan oleh Kitab Suci (Mat. 26:24), sumber utama yang sedang dirujuknya jelas kitab Daniel.

Lukas menulis bahkan lebih belakangan dari Matius, dan ia makin menjauh dari harapan-harapan Yahudi dan masuk ke dalam dunia yang lebih kosmopolitan, dunia orang-orang Yahudi perantauan dan bangsa-bangsa lain yang telah menjadi penganut agama Yahudi. Meskipun demikian, Lukas masih memakai frasa "Anak Manusia" sebanyak dua puluh tujuh kali. Pemakaian yang paling menonjol atas frasa ini ditemukan dalam rujukan-rujukannya kepada akhir dunia (pasal 17 dan 21). Menurut Lukas, figur yang akan muncul untuk menandai akhir sejarah adalah "Anak Manusia", sebuah jati diri yang, dalam Injil Lukas, diklaim Yesus untuk dirinya sendiri.

Yohanes hanya tiga belas kali menggunakan frasa "Anak Manusia", tetapi yang paling mencolok terdapat dalam kisahnya mengenai seseorang yang dilahirkan buta yang penglihatannya dipulihkan Yesus. Ketika bertemu orang ini, yang baru saja dikucilkan dari sinagoge, Yesus bertanya kepadanya, "Percayakah engkau kepada Anak Manusia?" (Yoh. 9:1-37). Ketika orang itu bertanya, "Siapakah Dia, Tuhan? Supaya aku percaya kepada-Nya", Yesus menjawab, "Engkau bukan saja melihat Dia; tetapi Dia yang sedang berkata-kata dengan engkau, Dialah itu!" Dengan demikian, Yesus ditafsirkan dalam dua peran sang Mesias. Ia dipandang sebagai "Anak Manusia" surgawi, hakim terakhir, dan juga sumber keutuhan kehidupan sekarang ini dalam dunia ini. Kedatangannya yang pertama disertai dengan serangkaian mukjizat penyembuhan yang menjadi tanda kedatangan kerajaan Allah; tetapi ia juga akan datang sebagai hakim terakhir pada akhir sejarah untuk mendirikan kerajaan Allah.

\section{Yesus Sebagai Sang Hamba}

Bangsa Yahudi dikalahkan Babel, pertama pada tahun 598 SM, kemudian dengan cara yang le- bih buruk dan melemahkan pada tahun 586 SM. Hanya orang lanjut usia, orang lumpuh, tuli dan buta di antara orang Yahudi yang ditinggalkan di Yudea. Penduduknya dicampur dengan orang asing dan bangsa lain yang memiliki "ilah-ilah palsu" dan adat istiadat asing. Semua lainnya dibawa ke Babel sebagai tahanan dan status mereka diubah menjadi para pekerja kelas bawah. Tanah yang ditinggalkan bangsa Yahudi dinajiskan, mereka percaya, oleh kehadiran banyak orang asing. Bahkan lebih buruk lagi, sementara orang Yahudi sedang dalam pembuangan, dibekas kampung halaman mereka banyak anak dilahirkan dengan darah yang tidak murni Yahudi lagi; hasilnya adalah orang Samaria. Orang Samaria ini dipercaya telah mengompromikan kemurnian rasial Yahudi, agama Yahudi dan kehormatan Yahudi.

\section{Yesus Sebagai Sang Raja Gembala}

Hal pertama yang harus dicatat adalah bahwa Zakharia secara tersurat maupun secara tersirat ada di belakang masing-masing injil kanonik. Tempat yang paling jelas, yang disebut sebelumnya, adalah kisah Yesus memasuki Yerusalem. Ayat ini sering kali dibaca sebagai pelajaran dari Kitab Suci Yahudi pada Minggu Palma: "Bersorak-soraklah dengan nyaring, hai Putri Sion, bersorak-sorailah, hai putri Yerusalem! Lihatlah, rajamu datang kepadamu; ia adil dan jaya. Ia lemah lembut dan mengendarai seekor keledai, seekor keledai beban yang muda." (Za. 9:9). Ditemukan banyak kesejajaran antara kisah Yesus dengan Zakharia jika kitab nabi ini dibaca dengan cermat. Para pedagang domba membayar sang "raja gembala" tiga puluh uang perak, tetapi kemudian uang ini disingkirkan darinya (Za. 11:12). Ia menolak pembayaran ini sebab ia tidak ingin lagi menjadi gembala mereka. Sang "raja gembala" lalu mengembalikan uang perak itu ke dalam perbendaharaan Bait Allah. Lalu, kata Zakharia, seluruh Yerusalem "memandang kepada dia yang telah mereka tikam, dan akan meratapi dia seperti orang meratapi anak tunggal, dan akan menangisi dia dengan pedih seperti orang menangisi anak sulung" (12:20). 
Tidak ada keraguan bahwa ketika teks-teks ini dibaca di sinagoge-sinagoge di antara murid-murid perdana Yesus, mereka memercayai bahwa semua itu sebenarnya ditulis berkaitan dengan Yesus. Dengan perayaan Paskah, alur kisah Zakharia ini mengalir dari prosesi Minggu Palma, masuk ke pengkhianatan terhadap Yesus, sampai pada penyaliban.

\section{Yesus: Seorang Manusia Untuk Semua Musim Yahudi}

Pada waktu Injil ditulis, Yesus ditafsirkan oleh dan dipahami melalui Kitab Suci Yahudi. Gambar-gambar mesianik Yahudi diterapkan kepadanya dan kehidupannya dibuat selaras dengan gambargambar itu. Kisah tentang kehidupannya diceritakan, disusun oleh tahun liturgis yang diikuti di sinagoge. Tahun liturgis ini kini diakui sebagai prinsip penyusunan dan penulisan Injil-Injil. Melalui prinsip ini, kata-kata dan perbuatan-perbuatan Yesus diingat, setidaknya dalam ketiga Injil pertama. ${ }^{15}$

\section{Supremasi Manusia Kristus Dalam Sejarah}

\section{Manusia}

Yesus bagi orang non religius: Yesus dulu sungguh Hidup, Allah yang dijumpai dalam Yesus, Yesus: penghancur batas kesukuan, Yesus: penghancur prasangka dan stereotip, Yesus: penghancur batas keagamaan, Salib: Gambaran Insani Kasih Allah.

\section{Yesus Dulu Sungguh Hidup}

Yesus dikenal sebagai Yesus dari Nazaret dan, karena Nazaret adalah kampung di Galilea, ia disebut orang Galilea. Markus dan Matius masingmasing merujuk pada Nazaret dalam empat kejadian berbeda. Dalam Injil Lukas terdapat delapan rujukan pada Nazaret, dan Lukas menyebutnya tujuh kali lagi dalam kitab Kisah Para Rasul. Yohanes menambah lima rujukan pada Nazaret di kisahnya, tiga di antaranya terdapat dalam kisah penyaliban, di mana

\footnotetext{
${ }^{15}$ Ibid, 242.
}

asal-usul Yesus dari Nazaret jelas tidak diragukan. Yesus pastilah berasal dari kota kecil Nazaret. ${ }^{16}$

\section{Allah Yang Dijumpai Dalam Yesus}

Allah yang dari atas masuk ke dalam dunia memerlukan suatu cara untuk masuk ke dalam gelanggang insani untuk melibatkan diri dalam situasi kehidupan manusia. Maka, suatu tempat pendaratan diciptakan untuk bisa menerima Allah yang datang itu. Orang Kristen mengidentisikasi tempat pendaratan itu sebagai kelahiran perawan. Melalui mujizat kelahiran perawan, Allah teistik mengenakan daging manusia dan berada di antara manusia. Sementara berada di bumi ini, Yesus ini dapat, sebagaimana ia digambarkan, melakukan semua hal yang orang anggap dapat dilakukan Allah sebab ia adalah Allah dalam rupa manusia. Demikianlah, diceritakan kisahkisah tentang Yesus menenangkan angin ribut, berjalan di atas air, melipatgandakan persediaan makanan, menyembuhkan orang sakit, dan bahkan membangkitkan orang mati.

\section{Yesus: Penghancur Batas Kesukuan}

Batas kesukuan yang Yesus hadapi terlihat dalam keretakan mendasar yang memisah-misah manusia yang membentuk pandangan dunia Yahudi. Orang Yahudi membagi dunia ke dalam anggotaanggota negeri kecil mereka sendiri, yang menyebut diri "kami", dan bangsa-bangsa lain, yang disebut "mereka". Orang Yahudi adalah "orang pilihan" Allah; sedangkan bangsa bukan Yahudi "orang bukan pilihan" Allah. Orang Yahudi yakin bahwa mereka mengetahui kehendak Allah sebab Allah telah memberi mereka kitab Taurat di Gunung Sinai, yang mengajari mereka cara hidup dan cara beribadah. Meskipun kehidupan Yesus di bumi ini berakhir sekitar tahun 30 Masehi, kuasa Yesus ini sedemikian rupa sehingga Paulus, yang menulis pada awal tahun lima puluhan, masih dapat membuat sebuah klaim yang sangat mengejutkan pada masa itu. Kepada

\footnotetext{
${ }^{16}$ Ibid, 248.
} 
jemaat di Galatia Paulus menulis bahwa di dalam pengalaman akan Kristus yang orang miliki bersama Yesus, semua hambatan kesukuan mereka hilang lenyap. Dalam Kristus "tidak ada orang Yahudi atau orang Yunani”, tidak ada orang Yahudi atau orang bangsa bukan Yahudi (3:28). Kepada jemaat di Roma, beberapa tahun kemudian, Paulus masih memegang pemahaman ini mengenai pengalaman akan Yesus ketika dia menulis bahwa keselamatan telah datang dari Allah dalam diri Yesus dan tersedia bagi "pertama-tama orang Yahudi, tetapi juga orang Yunani” (1:16). Beberapa ayat kemudian, Paulus mengatakan "Allah tidak memandang bulu" (2:11). Kemudian, Paulus menandaskan, "Sebab tidak ada perbedaan antara orang Yahudi dan orang Yunani. Karena, Allah yang satu ini adalah Tuhan dari semua orang, kaya bagi semua orang yang berseru kepadaNya. Sebab, "barangsiapa yang berseru kepada nama Tuhan, akan diselamatkan" (10:12-13). Ini adalah klaim-klaim yang mengejutkan. Kuasa Yesus telah memperluas batas-batas kesukuan Paulus dan, melalui dirinya, telah memampukan para pengikut Yesus merangkul dunia ini. ${ }^{17}$

\section{Yesus: Penghancur Prasangka dan Stereotip}

Yesus adalah seorang yang hidup seutuhnya. Sebagai hasilnya, ia melihat kemanusiaan dari suatu perspektif baru. Ia percaya bahwa kemanusiaan dalam diri seseorang dapat menyentuh kemanusiaan dalam diri orang lainnya dan memberdayakan orang lainnya itu untuk melangkah keluar dari ketakutanketakutan, sistem-sistem keamanan kesukuan, prasangka-prasangka yang menentukan, dan sempadansempadan lainnya yang di belakangnya manusia mencari suatu keamanan yang ada dalam bayangannya saja. Itu bukanlah sesuatu yang hanya Ia yang dapat perbuat: panggilan Allah yang dilihat dalam diri Yesus, seseorang yang manusiawi sepenuhnya, membuat makna kemanusiaan suatu karunia yang tersedia bagi setiap kehidupan. Itu sebabnya orang meli-

\footnotetext{
${ }^{17}$ Ibid, 290.
}

hat apa yang mereka sebut Allah dalam Yesus yang insani. Kemanusiaan Yesus membuka kehidupannya kepada semua makna Allah. Mereka yang mengalami Yesus mengalami kualitas baru kehidupan ini. Mereka melihatnya, merasakannya, dan mendapatkannya. ${ }^{18}$

\section{Yesus: Penghancur Batas Keagamaan}

Gereja dan negara selalu mencari kemampuan memaksakan keteraturan atas suatu dunia yang kacau dan telah terjatuh. Yesus, sebaliknya, tampaknya percaya bahwa kebutuhan abadi untuk mengontrol kehidupan melalui pemakaian aturan-aturan keagamaan tidaklah lebih daripada pelanggengan keadaan manusia yang tidak utuh. Agama yang otoriter hanya berkutat dalam pengendalian kerusakan. Tujuannya adalah tetap mengontrol kecenderungankecenderungan berbahaya manusia. Yesus melihat situasi manusia dengan sangat berbeda. Ia melihat kemanusiaan sebagai sebuah perjalanan keluar dari situasi dikontrol dan diatur masuk ke dalam kepenuhan dan keutuhan. Ia memanggil orang untuk melangkah melampaui aturan-aturan, pertahanan-pertahanan, batas-batas kesukuan, prasangka-prasangka, dan bahkan agama untuk menerima kehidupan yang berkelimpahan. Ini adalah suatu pendekatan unik terhadap kehidupan dan agama. Itulah sebabnya Yesus berbeda dengan sangat mengejutkan, ia tampak berasal dari suatu dimensi lain kemanusiaan, dan para pengikutnya mulai memandang Allah sebagai bagian jati dirinya. ${ }^{19}$

\section{Salib: Gambaran Insani Kasih Allah}

Kemanusiaan dalam kepenuhannya menjadi karunia tanda-tanda dan makna Allah. Kemanusiaan yang penuh mengalir masuk ke dalam realitas ilahi. Keilahian menjadi dan adalah kedalaman mendasar dari kemanusiaan. Allah bukanlah suatu kuasa adikodrati yang berlawanan dengan dunia dan kemanu-

\footnotetext{
${ }^{18}$ Ibid, 309.

${ }^{19}$ Ibid, 328.
} 
siaan. Makna dan realitas Allah ditemukan dalam pengalaman kepenuhan kemanusiaan yang mengalir dan memberi hidup melalui seluruh diri manusia. Allah dialami ketika kehidupan terbuka pada "kelainan" (otherness) adikodrati, ketika kehidupan dipanggil untuk melampaui setiap penghalang, lalu memasuki suatu kemanusiaan yang terus diperluas. Pengalaman akan Yesus dari abad pertama sangat sederhana, yakni orang bertemu Allah di dalam dirinya. "Allah di dalam Kristus", kata mereka, dan bersama mereka juga mengatakannya, karena kehidupan, kasih dan keberadaan mengalir melalui kepenuhan kemanusiaannya.

\section{RELEVANSI BAGI KEHIDUPAN ORANG KRISTEN}

Masa kini diakui luas bahwa hubungan antara agama-agama telah memasuki tahap baru. Interaksi ekonomi global, kesalingtergantungan sistem politik dan berbagai peristiwa global serta perluasan sistem komunikasi elektronik melintasi batas-batas nasional dan budaya telah menciptakan situasi tertentu. Situasi tersebut mempertemukan berbagai budaya berbeda dan tradisi keagamaan dengan cara yang tidak pernah terjadi sebelumnya. Hal ini dialami di banyak negara dan khususnya di kota-kota besar. Di tempat tersebut, gerakan populasi mengikuti kehancuran era kolonial dan arus pengungsi dari berbagai negara yang menderita karena konflik militer dan perang saudara. Kemiskinan serta perampasan hak masyarakat juga telah ikut mendorong munculnya masyarakat multi-budaya dan multi-agama yang menimbulkan tantangan luar biasa terhadap para anggotanya. Tantangan-tantangan ini berkaitan dengan konflik laten yang mungkin ada dalam situasi tersebut maupun kemungkinan pengayaan pengalaman yang mereka tawarkan. Banyak tanggapan teologis terhadap situasi baru ini masih memberikan kesaksian terhadap pengaruh-pengaruh sikap sesudahnya. Pengaruh sikap ini selama berpuluh tahun mengabaikan masalah-masalah teologi keagamaan atau pembahasannya yang eksklusif dalam teologi misi. Re- siko manajemen krisis dan improvisasi teoritis yang tergesa-gesa tidak selalu dapat dihindari.

Salah satu ciri pengakuan yang terlambat tentang hubungan antara agama-agama sebagai masalah teologis yang sangat penting adalah bahaya berkembangnya polarisasi di antara para teolog dalam tanggapan mereka terhadap situasi perjumpaan antar agama yang baru. Di satu pihak, ada kelompok-kelompok dan banyak di antara mereka menggambarkan dirinya sebagai evangelikal konservatif. Bagi mereka, situasi kontak baru di antara agama-agama menampilkan tantangan bagi pembaruan semangat misioner dalam menobatkan anggota agama-agama lain ke dalam kekristenan. Bagi sebagian dari mereka, Amanat Agung (Mat. 28:19-20) adalah kata pertama dan terakhir yang dapat dikatakan tentang agamaagama. Kekristenan tampaknya disajikan sebagai kepercayaan kaum eksklusivis dibandingkan dengan semua agama lain yang diperlihatkan sebagai bentuk kekafiran. Sementara harus diakui bahwa pendekatan ini mempertahankan perasaan iman Kristen yang kuat sebagai iman misioner, yang merupakan ciri khas identitas Kristen selama berabad-abad.

Pendekatan yang berlawanan dengan bentuk pemahaman kekristenan dan hubungannya dengan agama-agama lain ini ialah pendekatan yang secara programatis diajukan dalam buku Mitos Keunikan Agama Kristen: usul tentang pluralisme agama sebagai paradigma refleksi baru tentang hubungan antara agama-agama. Hal ini menampilkan dirinya sebagai "suatu upaya melangkah meninggalkan penekanan pada superioritas atau finalitas Kristus dan agama Kristen menuju pengakuan akan validitas mandiri dalam jalan-jalan lain. Namun demikian, sikap negatif terhadap pemahaman absolutisme dan eksklusivisme Kristen yang diajukan sebagian aliran dari penafsiran diri evangelikal konservatif kekristenan dan penggunaan programatis tentang istilah pluralisme dalam hampir semua penulis buku Mitos Keunikan Agama Kristen mempunyai kesamaan. Tempat berpijak mereka yang sama adalah kekristenan tidak dapat lagi berpura-pura berada dalam posisi istimewa 
karena mengklaim dirinya eksklusif, mutlak dan final; sebaliknya, ia harus dilihat "dalam konteks yang pluralistis sebagai salah satu kepercayaan dunia, sebagai salah satu arus kehidupan keagamaan yang dengannya manusia dapat dihubungkan dengan selamat kepada Realitas Utama yang dikenal orang Kristen sebagai Bapa Surgawi. ${ }^{20}$

\section{Ajaran Finalitas Kristus sebagai Penuntun Kehidupan Bersama Umat Lain}

Masyarakat Indonesia adalah masyarakat yang majemuk atau pluralis, baik dari dimensi budaya maupun agama. Dari zaman dahulu kala masyarakat Indonesia adalah masyarakat yang hidup bersama dengan rukun dan damai di tengah-tengah keragaman budaya dan agama. Dengan fakta yang ada di lapangan, di era modern, postmodern sampai era digital kini pun, kemajemukan selalu menjadi ciri khas bangsa Indonesia. Bahkan dengan bertambahnya kepercayaan dan agama yang diterima dan diakui di kementerian Agama Republik Indonesia, maka semakin maraklah pluralitas kehidupan beragama di nusantara ini. Bertolak dari kenyataan kemajemukan yang sesungguhnya merupakan aset kekayaan negeri ini, maka upaya untuk mempertahankan dan menstabilkan kerukunan hidup bersama adalah sebuah upaya beriman seperti yang ditulis oleh Sitohang:

Kenyataan banyaknya agama mengakibatkan umat beriman untuk merumuskan sikap teologis untuk menjawab realitas itu. Hal ini merupakan upaya iman, karena dalam konteks kekristenan beriman sebagai seorang Kristen akan mendorong untuk melihat dan berkata sesuatu terhadap agama lain dengan kaca mata iman. ${ }^{21}$

Berangkat dari memahami agama sebagai hal pokok untuk dihidupi dan dihayati, maka penulis memandang perlu untuk memiliki landasan sikap untuk da-

\footnotetext{
${ }^{20}$ Gavin D'Costa, Mempertimbangkan Kembali Keunikan Agama Kristen (Jakarta: BPK Gunung Mulia, 2002), 71.

${ }^{21}$ Ance M. D. Sitohang, "Hidup Bersama Dalam Masyarakat Pluralistik" http://forumteologi.com/blog/ 2007/05/22/hidup-bersama-dalam-masyarakatpluralistik/
}

pat menjaga kelangsungan kehidupan bersama para umat yang lain agama. Dan Indonesia memiliki semboyan hidup kebersamaan yang luar biasa yakni "Bhineka Tunggal Ika".

Bangsa Indonesia memiliki filosofi agar selalu hidup bedampingan dengan damai dalam masyarakat yang berbeda suku, bangsa, ras dan antar golongan. Kehidupan berbangsa dan bermasyarakat diajak untuk mengerti, menghayati dan melaksanakan kehidupan bersama ke arah terciptanya persatuan dan kesatuan yang bersemboyan "Bhineka Tunggal Ika" yang artinya walaupun berbeda-beda tetapi tetap bersatu. Erat kaitannya dengan menghargai dan menghayati perbedaan suku bangsa, agama, ras dan golongan sebagai unsur utama untuk mempersatukan dan bukan sebaliknya untuk terjadi konflik sosial maka ajakan agar selalu hidup berdampingan secara damai merupakan bentuk sosialitas nilai yang terkandung dalam multi kulturalisme dan pluralisme. Beranjak dari sini maka penulis melihat ada nilai atau kontribusi yang dapat dimasukkan ke dalam masyarakat Indonesia yang sangat beragam suku, agama ras dan antar golongan.

\section{Memperkenalkan Figur Yesus yang Lemah Lembut dalam Kesaksian Hidup Orang Percaya ketika Berinteraksi dalam Masyarakat}

Sebagaimana telah dibahas di dalam bagian mengenai supremasi Kristus yang sudah teruji dan terbukti, maka kontribusinya di dalam masyarakat majemuk di Indonesia, justru perlu memproklamasikan figur Yesus Kristus yang lemah lembut seperti Ia sendiri juga mengakuinya:

Marilah kepadaku, semua yang letih lesu dan berbeban berat, Aku akan memberi kelegaan kepadamu. Pikullah kuk yang Kupasang dan belajarlah pada-Ku, karena Aku lemah lembut dan rendah hati dan jiwamu akan mendapat ketenangan. ${ }^{22}$

Yesus telah memberi contoh yang baik kepada banyak orang dengan sifat-Nya yang lemah lembut.

${ }^{22}$ Matius 11:28-29 
Orang banyak datang kepada-Nya bukan karena Ia menyiarkan suatu agama yang baru, melainkan karena daya tarik dan kuasa yang berasal dari diri-Nya sendiri. Bila demikian halnya kesaksian pribadi yang memiliki kuasa dan supremasi atas segala sesuatu, begitu juga para pengikut-Nya hari ini yang hendak menjadi alat berkat di masyarakat Indonesia. Orang percaya yang bersaksi di dalam kehidupan bersama dengan umat yang lain perlu memiliki sikap yang sama. Tujuan kehadiran dan keikutan orang Kristen berbaur dengan umat lain di masyarakat bukanlah memperkenalkan agama yang dianut oleh orang percaya itu sendiri melainkan memperkenalkan figur Yesus hidup dan memberi kuasa di dalam diri orang percaya tersebut.

\section{Memperkenalkan Figur Yesus yang Mau Bergaul dengan Orang Berdosa di dalam Masyarakat}

Yesus Kristus di masa hidupnya, ketika sedang berkiprah di dalam pelayanan di dalam masyarakat Yahudi, pernah dikritik karena Ia bergaul dengan orang-orang berdosa. Matius menulis kenyataan itu sebagai berikut: "Kemudian Anak Manusia datang, Ia makan dan minum, dan mereka berkata: Lihatlah, Ia seorang pelahap dan peminum, sahabat pemungut cukai dan orang berdosa. Tetapi hikmat Allah dibenarkan oleh perbuatannya." ${ }^{, 3}$ Beranjak dari fakta ini bahkan Yesus sendiri pernah bersabda, "sama seperti Anak Manusia datang bukan untuk dilayani, melainkan untuk melayani dan untuk memberikan nyawa-Nya menjadi tebusan bagi banyak orang." (Mat. 20:28). Seperti yang telah disebutkan di bagian terakhir, Yesus Kristus adalah tebusan yang dibayarkan untuk membebaskan manusia dari semua dosa, dari segala kejahatan seperti yang tertulis di dalam Titus 2:14. Namun perlu dijelaskan bahwa yang dimaksud semua di sini adalah dosadosa yang orang lakukan seumur hidupnya, juga termasuk dosa yang Adam lakukan ketika ia jatuh, yang menurun dari generasi ke generasi kepada se-

\footnotetext{
${ }^{23}$ Matius 11:19
}

mua manusia, sehingga menjadikan mereka semua orang-orang berdosa sejak mereka dilahirkan. Sebagaimana tertulis di dalam Roma 5:18-19.

\section{Ajaran Supremasi Kristus sebagai Penuntun Kehidupan Beriman Sesama Umat Kristen}

\section{Menghidupi Matriks Kepercayaan}

Setiap agama mempunyai matriks kepercayaan. Andreas Himawan berpendapat bahwa gereja yang menghidupi matriks itu akan memantulkan keluar semua pengalamannya. ${ }^{24}$ Lumintang juga menandaskan bahwa tanda-tanda Tuhan mempertahankan tentang supremasi Kristus tampak pada kesetiaan umat percaya pada Alkitab yang dibingkai oleh Injil. Kristen unggul karena Kristus. ${ }^{25}$ Kristologi adalah bidang ilmu (teologi) yang secara khusus memahami Yesus. Memahami Yesus berarti memahami keselamatan (soteriology). Upaya ini dilakukan gereja bukan semata-mata untuk ortodoksi (menjaga keaslian), apalagi untuk 'pengetahuan' saja. Upaya ini berhubungan dengan keselamatan dunia. Pengkajian Kristologi juga beragam, jadi bukan hanya agama yang plural. Kristologi juga plural, karena orang mempunyai harapan yang berbeda, berada dalam posisi yang berbeda, mempunyai paham yang berbeda tentang inti keselamatan. Meski beragam, semuanya berintikan keselamatan (soteriology) Allah. Yesus Kristus menentukan Soteriology Allah. Yesus adalah Tuhan, berarti Dia juga adalah Tuhan atas keselamatan. ${ }^{26}$ Agar keselamatan tetap terjaga dan terpelihara di dalam kehidupan praktis tri panggilan gereja.

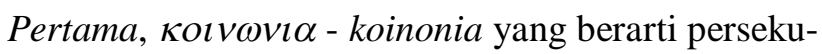
tuan dengan partisipasi intim. Kata ini sering digunakan dalam Perjanjian Baru dari Alkitab untuk menggambarkan hubungan dalam gereja Kristen per-

\footnotetext{
${ }^{24}$ Andreas Himawan, Wawancara oleh penulis, September 2014.

${ }^{25}$ Stevri Lumintang, Wawancara oleh penulis, Juli 2014.

${ }^{26}$ Pinehas Djenjengi, Makalah dalam ibadah kapel STT Jaffray Jakarta, September 2014.
} 
dana serta tindakan memecahkan roti dalam cara yang ditentukan Kristus selama perjamuan Paskah (Yoh. 6:48-69; Mat. 26:26-28; I Kor. 10:16, 11:24). Akibatnya kata tersebut digunakan dalam gereja Kristen untuk berpartisipasi, seperti kata Paulus, dalam persekutuan dengan cara ini mengidentifikasi keadaan ideal persekutuan dan masyarakat yang harus ada persekutuan. ${ }^{27}$ Dengan demikian koinonia berarti mencakup unsur beribadah. Untuk melaksanakan panggilan gereja yang pertama maka pemberitaan Firman Allah mesti senantiasa dilakukan secara berkesinambungan dengan tujuan seperti yang ditulis oleh John Piper, tujuan pemberitaan Firman Allah adalah untuk membangkitkan "afeksi kudus" hal-hal seperti membenci dosa, bersuka di dalam Allah, berharap pada janji-janji-Nya, bersyukur atas kemurahan-Nya, hasrat untuk kekudusan, belas kasihan yang lembut. Alasan untuk ini adalah bahwa ketiadaan afeksi kudus dalam orang-orang Kristen adalah keadaan yang menjijikkan. ${ }^{28}$

Yesus Kristus pernah mengutip perkataan nabi Yesaya, "Bangsa ini memuliakan Aku dengan bibirnya, padahal hatinya jauh dari pada-Ku. Percuma mereka beribadah kepada-Ku, sedangkan ajaran yang mereka ajarkan adalah perintah manusia" (Mat. 15:8-9). Permasalahannya adalah Allah dengan penduduk Yerusalem dan Kristus dengan kaum Farisi, bukannya mereka memuliakan Allah, melainkan sebaliknya, mereka melakukannya dengan cara yang salah. Padahal setiap orang percaya mestinya memuliakan Allah seperti yang ditulis oleh John Stott:

Setiap orang harus memuliakan Allah dengan memberi-Nya kemuliaan dan pujian yang layak Ia terima. Sesungguhnya, inilah arti ibadah. Kata ini sudah cukup jelas. Karena worship (ibadah atau penyembahan) adalah bentuk pendek dari 'worthship' (menyatakan bahwa Allah layak atau pantas atas penyembahan). Kata ini mengindikasikan bahwa Allah layak disembah. Bahwa ibadah adalah pengakuan yang pantas bagi Dia

\footnotetext{
${ }^{27}$ id.m.wikipedia.org/wiki/Koinonia

${ }^{28}$ John Piper, Supremasi Allah dalam Khotbah (Surabaya: Momentum, 2008), 80.
}

yang paling layak menerimanya. Dalam ibadah, kita datang kepada-Nya - sebagai ciptaan yang memuliakan Penciptanya, sebagai orang-orang berdosa yang memuliakan Juruselamatnya, sebagai anak-anak yang memuliakan Bapanya, dan sebagai para pelayan yang memuliakan Tuannya. Oleh karena itu, ibadah bukan aktivitas pilihan yang dapat ditambahkan pada jadwal sehari-hari oleh mereka yang menyukainya dan diabaikan oleh mereka yang tidak menikmatinya. Ini adalah kewajiban, karena ini adalah pengakuan atas fakta. $^{29}$

Selanjutnya, tugas panggilan gereja yang kedua adalah diakonia itu bersifat hakiki bagi jemaat lokal. Sebagaimana Kristus telah melayani manusia, demikian pula setiap pengikut-Nya harus melayani sesa-

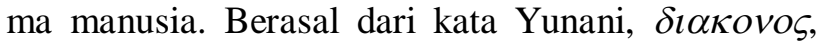
berarti abdi atau pelayan. Pada jemaat mula-mula, diakonia berarti pelayanan meja perjamuan sehingga manusia menjadi layak sebagai umat Allah. Diakonia mewujud di dalam jemaat-jemaat setempat, karena di dalam konteks setempat gereja/jemaat harus menjadi pelayan Tuhan. Ia terbuka untuk melayani kebutuhan manusia di mana gereja itu berada. Dengan demikian ia bersaksi. ${ }^{30}$

Pelayanan berarti melakukan pekerjaan baik yang ditujukan untuk melayani Allah dengan melayani sesama manusia. Hal ini berbicara tentang keluar dari zona nyaman diri sendiri untuk melakukan perbuatan baik yang bermanfaat bagi orang lain. Boice mengartikan dengan sangat gambang di dalam bukunya mengenai melayani:

Tentu saja lebih mudah untuk melayani diri kita sendiri. Tetapi kita tidak boleh demikian. Pertama, kehadiran pekerjaan baik di dalam kehidupan orang Kristen adalah satu bukti dari keselamatan. Sekarang kita berpikir secara berbeda dari cara pikir kita sebelum pertobatan, dan berusaha melayani orang-orang lain dalam cara-cara yang tidak pernah terjadi pada kita sebelumnya. Inilah bukti kita adalah ciptaan-ciptaan baru dalam Kristus. Ekspresi kasih yang praktis kepada orang-orang lain adalah satu bukti dari kehi-

\footnotetext{
${ }^{29}$ John Stott, Kristus Sang Kontroversialis (Surabaya: Literatur Perkantas Jawa Timur, 2014), 166.

${ }^{30} \mathrm{https}$ ://einsthitler.wordpress.com/2010.
} 
dupan baru yang disajikan oleh Rasul Yohanes. "Kita tahu, bahwa kita sudah berpindah dari dalam maut ke dalam hidup, yaitu karena kita mengasihi saudara kita" (I Yoh. 3:14). ${ }^{31}$

Ketika seorang Kristen sudah terlibat aktif di dalam melayani, maka secara otomatis akan mengalir keluar energi untuk bersaksi yang juga merupakan panggilan ketiga dari tugas gereja yakni marturia ( $\mu \alpha \rho \tau v \rho \imath \alpha$ - bahasa Yunani) adalah salah satu istilah yang dipakai gereja untuk melakukan aktivitas imannya, sebagai tugas panggilan gereja, yaitu dalam hal kesaksian iman. Kesaksian iman yang dimaksud adalah pemberitaan Injil sebagai berita keselamatan bagi manusia. ${ }^{32}$ Bila gereja sudah menghidupi tri tugas panggilan gereja tersebut, maka itu adalah langkah standar untuk menjadi alat berkat bagi kalangan sendiri sebagai orang Kristen maupun menjadi saluran berkat bagi umat lain.

\section{Menghayati Kekhasan Multi Dimensi}

Setiap agama memiliki ciri-ciri khas, baik dari ajaran, ritual maupun gaya hidup umatnya, termasuk Kristen. Martin Sinaga mengibaratkan bahwa upaya menjaga kekhasan itu seperti tarian Ilahi, multidimensi. Basis ini sangat Kristen dan subjektif. ${ }^{33}$ Sikap Kristen adalah tidak kompromistis, mengacu kepada sifat alkitabiah. Karena berpatokan kepada Yesus Kristus yang bisa hidup rukun, bersahabat dengan agama dan orang lain. Orang Kristen percaya bangsa-bangsa akan menyembah Tuhan. Keunikan kepercayaan ini tetap dipertahankan. Dengan berpegang pada prinsip ajaran alkitabiah. ${ }^{34}$ Dengan menghayati kekhasan multi dimensi yang terdapat di dalam kekristenan baik dari sisi ajaran, liturgi, ibadah, pelayanan dan kesaksian, maka ke depannya diha-

\footnotetext{
${ }^{31}$ James Montgomery Boice, Dasar-Dasar Iman Kristen (Surabaya: Momentum, 2011), 584.

${ }^{32}$ id.m.wikipedia.org/wiki/Marturia

${ }^{33}$ Martin Sinaga, Wawancara oleh penulis, Oktober 2014. 2014.
}

rapkan ada perbaikan relasi antara orang Kristen dengan orang lain maupun dalam kalangan Kristen.

\section{KESIMPULAN}

Dalam upaya mengatasi konflik agama di Indonesia, maka toleransi masih menjadi andalan bangsa Indonesia. Khususnya bagi orang Kristen, toleransi sangatlah penting untuk membangun komunikasi yang sehat antar sesama umat yang tidak seiman. Konflik agama di Indonesia merupakan konflik yang sudah ada sejak adanya kemajemukan agama di Indonesia. Demikian pula pemerintah masih melihat toleransi merupakan kekuatan untuk mengatasi persoalan tersebut. Demikian juga dalam perspektif Kristen, toleransi tetap menjadi kekuatan untuk membangun komunikasi yang sehat dalam konteks pluralitas di Indonesia. Toleransi yang dapat diterapkan adalah melalui dialog kehidupan, bukan sekadar dialog melalui pertemuan-pertemuan formal para pemimpin agama.

Dalam konteks kemajemukan di Indonesia, seperti yang diungkapkan Stevri Indra Lumintang maka toleransi melalui dialog kehidupan, tidak hanya untuk mengantisipasi konflik antar agama, melainkan juga sebagai upaya untuk menciptakan persatuan dan kesatuan bangsa; mewujudkan toleransi sampai ke lapisan bawah masyarakat, karena pemahaman melalui dialog formal, biasanya hanya sampai pada kalangan elit. Dialog non-formal yang dibangun melalui pendekatan persahabatan atau persaudaraan anak-anak bangsa, masih sangat relevan sebagai wadah pewujudan toleransi antar umat beragama dan bahkan masih tetap menjadi wadah pekabaran Injil yang efektif. Toleransi dan dialog antar pribadi lebih efektif dari pada toleransi dan dialog antar kelompok. Toleransi dan dialog ini harus diawali dengan toleransi dan dialog kehidupan yang didasarkan pada kasih Kristus yang menguasai orang Kristen. ${ }^{35}$ Dengan pemahaman, sikap dan pende-

${ }^{35}$ Stevri Indra Lumintang, Theologia Abu-abuPluralisme Agama (Malang: Gandum Mas, 2009), 288. 
katan yang demikian, maka finalitas Kristus masih sangat relevan untuk diejawantahkan di tengah-

\section{DAFTAR RUJUKAN}

Baker, David L. Satu Alkitab Dua Perjanjian. Jakarta: Gunung Mulia, 2006.

Berkhof, Louis. Teologi Sistematika. Jakarta: Lembaga Reformed Injili Indonesia, 1996.

Boice, James Montgomery. Dasar-Dasar Iman Kristen. Surabaya: Momentum, 2011.

Costa, Gavin D. Mempertimbangkan Kembali Keunikan Agama Kristen. Jakarta: Gunung Mulia, 2002.

Darmawan, I Putu Ayub. "Pendidikan Kristen Di Era Postmodern", Jurnal Simpson: Jurnal Teologi dan Pendidikan Agama Kristen, Volume 1, Nomor 1, Juli 2014: 37-46. http://journal.sttsimpson.ac.id/index.php/Js/article/ view/3/2

Fernando, Ajith. Supremasi Kristus. Surabaya: Momentum, 2006.

Hasel, Gerhad F. Teologi Perjanjian Lama. Malang: Gandum Mas, 1992.

N.n. Universitas Sumatera Utara. tengah arus pluralisme serta pluralitas masyarakat Indonesia pada masa kini.

Objantoro, Enggar. "Pluralisme Agama-Agama: Tantangan Bagi Teologi Kristen", Jurnal Simpson: Jurnal Teologi dan Pendidikan Agama Kristen, Volume 1, Nomor 1, Juli 2014: 61-80. http://journal.sttsimpson.ac.id/ index.php/Js/article/view/3/2.

Piper, John. Supremasi Allah dalam Khotbah. Surabaya: Momentum, 2008.

Sihotang, Ance M. D. "Hidup Bersama Dalam Masyarakat Pluralistik" http://forumteologi.com/blog/2007/05/22/hidup-bersamadalam-masyarakat-pluralistik/

Spong, John Shelby. Yesus Bagi Orang Non Religius. Jakarta: Gramedia, 2008.

Stott, John. Kristus Sang Kontro Versialis. Surabaya: Literatur Perkantas Jawa Timur, 2014.

Stott, John. Kristus yang Tiada Tara. Surabaya: Momentum, 2007. 